\title{
SPACE DISTRIBUTION OF BACTERIAL COMMUNITIES AND SUBSTRATE ENZYMES IN VERTICAL FLOW CONSTRUCTED WETLANDS
}

\author{
XU, Q. L. ${ }^{*}-$ CAI, X. J. - FU, L. - HU, Y. \\ Department of Resources \& Environmental Engineering, Anshun University \\ Anshun 561000, China \\ *Corresponding author \\ e-mail: amy.198510@163.com; phone: +86-1898-4089-040 \\ (Received 13 ${ }^{\text {th }}$ Jul 2019; accepted $25^{\text {th }}$ Nov 2019)
}

\begin{abstract}
Microbial communities and substrate enzymes play a key role in constructed wetlands (CWs), therefore it's important to understand the diversity of microbial communities and activities of enzymes therein. In this study, System A (planting with Pennisetum sinese Roxb); System B (planting with Pennisetum purpureum Schum.); and System C (no plant) -- were set to investigate the variation of species richness, community equitability and substrate enzymes. It showed that Betaproteobacteria were most abundant in these three systems. The number of microorganisms species in system A, system B and system $\mathrm{C}$ were $60-90 \mathrm{~cm}>30-60 \mathrm{~cm}>0-30 \mathrm{~cm}, 60-90 \mathrm{~cm}>0-30 \mathrm{~cm}>30-60 \mathrm{~cm}$ and $30-60 \mathrm{~cm}>$ $60-90 \mathrm{~cm}>0-30 \mathrm{~cm}$, respectively. But urease, phosphatase and cellulose were all reduced with the increase of matrix depth. The results showed that the enzyme activity was not necessarily related to the number of microorganisms species, but enzyme activity could be related to the population of corresponding functional bacteria. In conclusion, Proteobacteria, Bacteroidetes, Firmicutes, Acidobacteria, Chloroflexi, Verrucomicrobia, Actinobacteria, TM7, Nitrospira, and OP11 were detected in these three constructed wetlands. However, there are still about $10 \%$ unknown bacteria at class level. The specific relationship between microorganisms, enzymes and wetland pollutant removal remains to be further studied in the future indicating that wetland microbial research has great potential in the future.

Keywords: vertical flow constructed wetland, microbial communities, substrate enzymes, Pennisetum sinese Roxb, Pennisetum purpureum Schum
\end{abstract}

\section{Introduction}

Constructed wetland $(\mathrm{CW})$ is a prospective sewage purification technology (Kadlec and Knight, 1996; Cui et al., 2013). Compared with traditional sewage treatment methods, CW has the simple technology, relatively low operation and maintenance requirements (Zuritaa et al., 2009; Tang et al., 2017). CWs mainly include 2 types, which are surface flow CW and subsurface flow CW (IWA, 2000; Kadlec and Wallace, 2008; Vymazal and Kröpfelová, 2008). Vertical flow constructed wetland (VFCW) is a kind of subsurface flow wetland (Xu et al., 2015). In the last two decades, VFCW technology has become a popular choice for sewage treatment (Prochaska and Zouboulis, 2006; Abou-Elela et al., 2012), because it is high-efficiency not only for mitigation of biochemical oxygen demand and total suspendedsolids (Vymazal, 2009) but also for nitrification even in winter (Arias et al., 2005; Cooper, 2005; Prochaska et al., 2007). The VFCW with unsaturated flow has stronger oxygen carrying capacity than horizontal underground flow and is more effective for the mineralization of biodegradable organics (Kantawanichkul et al., 2009). As we all know, the main mechanism of $\mathrm{CW}$ sewage purification is the interaction of substrate, vegetation and microorganism through a series of biological, physicochemical reactions (Truu et al., 2009; Fu et al., 2013). Wetlands vegetation can affect enzyme activity and microbial 
species structure and diversity that in turn indirectly affect enzyme activity (Zhang et al., 2010). Therefore, it's important to see the activities of enzymes and diversity of microbial population in constructed wetland. Wang (2009) proposed that the number of microorganisms, bacterial diversity and dominant community in the wetland system are closely relevant to the removal of phosphorus, nitrogen and organic compounds. Zhang et al. (2010) wetlands contains a wide range of cellulose and glycosidase, protease, urease, phosphatase, phenol oxidase and other enzymes. In our preliminary study, based on the study of the microbial enzyme activity in the artificial wetland system, the urease activity in the root system of aquatic plants was considered as an important index of nitrogen purification (Cui et al., 2013). In this study, several important bacterial communities (Proteobacteria, Bacteroidetes, Chloroflexi, Nitrospira, and OP11 etc.) and activities of substrate enzymes related to $\mathrm{C}, \mathrm{N}$ and $\mathrm{P}$ cycle was analyzed, employing Illumina high-throughput sequencing technology and zymological means. The objective of this study is to estimate the space distribution of bacterial community and enzyme activities in the VFCW system. It is expected to provide a theoretical basis for microbial regulation of VFCW.

\section{Materials and methods}

\section{Construction of VFCW}

Three vertical wetlands were established and maintained in the greenhouse facility of South China Agriculture University (SCAU) in Guangzhou city. Each system was structured at $200 \mathrm{~cm} \times 100 \mathrm{~cm} \times 130 \mathrm{~cm}$ (length x wide x height). These three systems were constructed as followed: System A planted with Pennisetum sinese Roxb, System B planted with Pennisetum purpureum Schum., and System C planted nothing. The sketch map of the $\mathrm{CW}$ systems was seen in Figure 1. The vegetation types of Pennisetum sinese Roxb and Pennisetum purpureum Schum. were transplanted into A, B system respectively, and the density is $10 \mathrm{plant} / \mathrm{m}^{2}$.

(a)

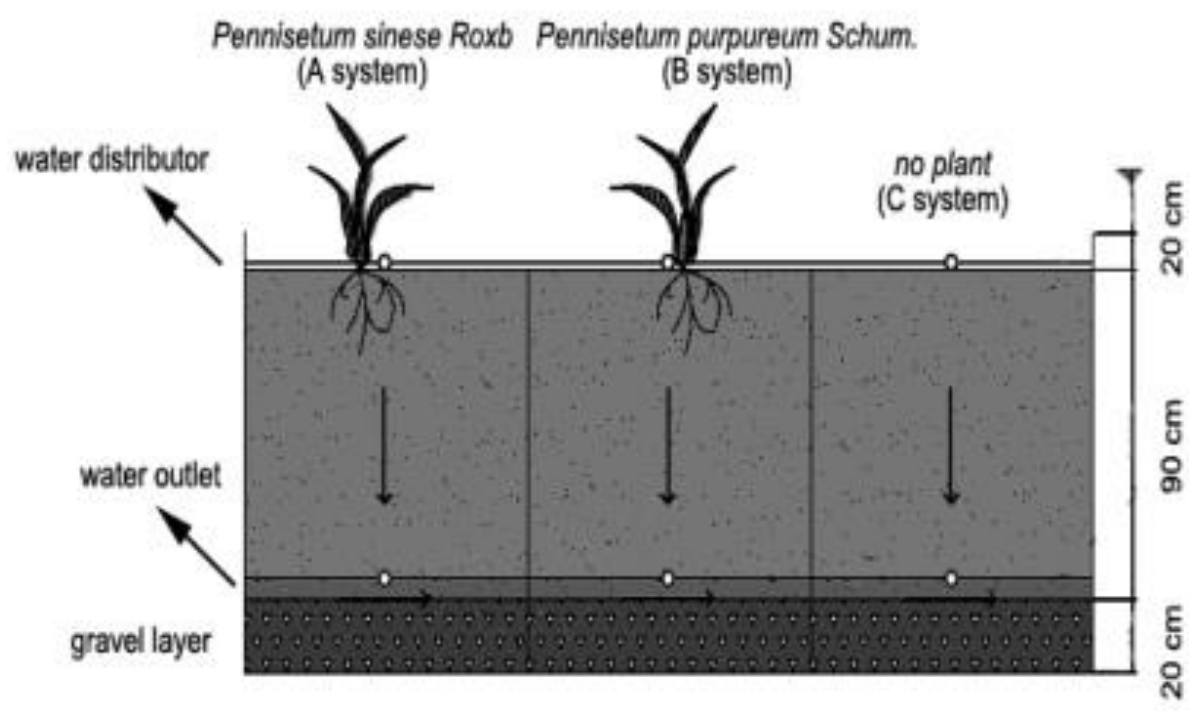

Figure 1. The profile of wetland system 


\section{Synthetic sewage}

The synthetic wastewater is prepared from 400 litres of tap water, $70 \mathrm{~g}$ milk powder, $60 \mathrm{~g}$ soluble starch, $18 \mathrm{~g}$ urea, $10 \mathrm{~g}\left(\mathrm{NH}_{4}\right)_{2} \mathrm{SO}_{4}, 6 \mathrm{~g} \mathrm{MgSO}_{4}, 6 \mathrm{~g} \mathrm{KH} \mathrm{KO}_{4}, 60 \mathrm{~g} \mathrm{NaHCO} 3$, and $50 \mathrm{ml} 1 \% \mathrm{FeCl}_{3}$. Water quality indicators were as follows: the average values of $\mathrm{TN}$, TP and COD were $40 \mathrm{mg} / \mathrm{L}, 4 \mathrm{mg} / \mathrm{L}$ and $330 \mathrm{mg} / \mathrm{L}$. The $\mathrm{pH}$ value was 6.39-6.7 and the DO value was 4-6.

\section{Operation of constructed wetland}

Each CW system was constructed in mid-March, then started to operate on $28^{\text {th }}$ of March and at last ended on $26^{\text {th }}$ of September. These three systems carried out at $20 \mathrm{~cm} / \mathrm{d}$ hydraulic loading. The sewage was feeded on $28^{\text {th }}$ of March, these three systems were irrigated continuously with sewage for 8 hours every day. On $11^{\text {th }}$ of April, we collected the water from the outlet position and analyzed once a week. The water monitoring indexes include TN, TP and COD etc. The over ground part of system vegetations were reaped once a month. By the end of the trial, five substrate samples were collected individually from 0-30 cm layer, 30-60 cm layer and 60-90 cm layer in every constructed wetland. These five samples were blended to get one typical sample for each layer. The community structure and diversities were monitored, by using Highthroughput Sequencing Techniques and the enzyme activities were measured by zymological methods. The basic information of soil samples are shown in Table 1.

Table 1. Basic information of sample (DNA samples)

\begin{tabular}{c|r|c|c}
\hline $\begin{array}{c}\text { Sample } \\
\text { number }\end{array}$ & Constructed wetland & Depth(cm) & Code \\
\hline 1 & A (planting with planting Pennisetum sinese Roxb) & $0-30$ & A1 \\
2 & A (planting with planting Pennisetum sinese Roxb) & $30-60$ & A2 \\
3 & A (planting with planting Pennisetum sinese Roxb) & $60-90$ & A3 \\
4 & B (planting with Pennisetum purpureum Schum.) & $0-30$ & B1 \\
5 & B (planting with Pennisetum purpureum Schum.) & $30-60$ & B2 \\
6 & B (planting with Pennisetum purpureum Schum.) & $60-90$ & B3 \\
7 & C(no plant) & $0-30$ & C1 \\
8 & C(no plant) & $30-60$ & C2 \\
9 & C(no plant) & $60-90$ & C3 \\
\hline
\end{tabular}

Note: A $(1,2,3)$ indicates that the sampling depth in system A is $0-30 \mathrm{~cm}$ (top layer), $30-60 \mathrm{~cm}$ (middle layer), and 60-90 cm (bottom layer), respectively. B $(1,2,3), \mathrm{C}(1,2,3)$ were set in the same way

\section{DNA extraction}

DNA was extracted from matrix samples using the Power Soil DNA separation kit (Mobio Laboratories Inc., Carlsbad, CA, USA) in accordance with the manufacturer's protocol. The extraction quantity and quality of DNA were determined by spectrophotometry. The extracted DNA before further analysis is stored in $-80^{\circ} \mathrm{C}$. 


\section{PCR detection}

The V3-V4 region (338F-806R) of $16 \mathrm{~S}$ rRNA was amplified by PCR with the primers $\quad 338 \mathrm{~F} \quad\left(5^{\prime}\right.$-ACTCCTACGGGAGGCAGCA-3') and 806R (5'GGACTACHVGGGTWTCTAAT-3') (Wang et al., 2014; Lin et al., 2018).

These PCR reactions were proceed in a 30 ul reaction mixture, including 0.75 units Ex Taq DNA polymerase, $1 \times$ Ex Taq loading buffer, $0.2 \mathrm{mM}$ dNTP mix, $0.2 \mu \mathrm{M}$ of each primer, and $100 \mathrm{ng}$ template DNA.

The amplification of each specimen was carried out in triplicate in an Eppendorf Master cycler PC.

\begin{tabular}{ll|l}
$94^{\circ} \mathrm{C}$ & $30 \mathrm{~s}$ & 35 cycles \\
$50^{\circ} \mathrm{C}$ & $1 \mathrm{~min}$ & \\
$72^{\circ} \mathrm{C}$ & $1 \mathrm{~min}$ & \\
$72^{\circ} \mathrm{C}$ & $10 \mathrm{~min}$ &
\end{tabular}

The PCR production was replicated and its concentration was monitored in a $2 \%$ agarose gel, Amplicons of all specimen were collected at the same ratio and the mixture was purified using the Gel Extraction Kit (E.Z.N.A.TM). Purified and mixed PCR products meet the requirements and were sequenced based on Illumina Miseq PE (paired end) 280bp.

\section{Statistical analysis}

Microbiological information analysis: the purified mixed PCR products were used for high throughput sequencing. Using Mothur (V.1.36.1) the original DNA sequence was filtered to remove chimeras and obtain the optimized sequence; According to $97 \%$ similarity, the optimized sequence is divided into Operational Taxonomic Units (OTU). Species taxonomy: A total of 6752 OTUs were obtained from 9 soil samples. Of the 6751 OTUs species in the sample, $5693(84.3 \%)$ were at least accurate to phylum level and $5173(76.6 \%)$ were at least to class level. Venn diagram analysis: It can be used to count the number of common or unique OTU in multiple samples, and can intuitively show the degree of similarity of OTU composition among environmental samples. water quality and soil enzymes were analyzed by EXCEL2007 and SPSS17.0. A one-way analysis of variance was conducted for constructed wetland: system A (planting Pennisetum sinese Roxb), system B (planting Pennisetum purpureum Schum.) and system $\mathrm{C}$ (no plant), to be detected the statistical significance of differences $(p<0.05)$ between means of treatments, and the Duncan test was performed.

\section{Enzymes activities measured}

Urease activity was measured by phenol-sodium hypochlorite method. The determination of urease activity in soil is based on the amount of ammonia produced after the enzymatic reaction with urea as the substrate, and can also be obtained by measuring the amount of unhydrolyzed urea. In this method, the urease liveness was analyzed by taking urea as the zymolyte, and the blue indophenol was produced by the reaction of the enzyme product ammonia with phenol-sodium hypochlorite. Phosphatase was measured by disodium phenyl phosphate method. In this method, the activity of the enzyme is expressed by the amount of phenol produced by hydrolyzing the substrate with phosphodisodium phosphate as the substrate under the action of phosphatase (Guan, 1986). 


\section{Results}

\section{Microbial community composition}

At the phylum level, 26 phyla of bacterial, 523 genera were identified in this study. Among 9 substrate samples, Proteobacteria (averaging 55.1\%) was the most abundant phyla, followed by (averaging 10.2\%), unclassified (averaging 8.0\%), Firmicutes (averaging 6.6\%), Acidobacteria (averaging 5.3\%), and Chloroflexi (averaging 4.7\%). The other predominant phyla $(>1 \%)$ were Verrucomicrobia (averaging $1.9 \%$ ), Actinobacteria (averaging 1.8\%), TM7 (averaging 1.6\%), Nitrospira (averaging 1.4\%), and OP11 (averaging 1.1\%). Furthermore, their relative abundance of these predominant bacterial populations usually exhibits significant spatial variability in every system.

From Figure 2(a), it showed that there was a large difference in bacterial flora among the three constructed wetlands. Proteobacteria was dominant in 9 studied samples. The spatial variation of the proportion of proteobacteria in VFCW has rarely been studied. In this experiment, the analysis on community of wetland microorganisms showed the advantage of proteobacteria in vertical flow to CW. However, a relatively high proportion of proteobacterial was found in the systems of planting with planting Pennisetum sinese Roxb and with Pennisetum purpureum Schum., while the system with no plants showed a decrease. The abundance of the Chloroflexi in system A (planting with Pennisetum sinese Roxb) and B (planting with Pennisetum purpureum Schum.) was higher than that of system $C$ (no plant). At the same time, the abundance of Chloroflexi phylum increased as the substrate depth deepen. Chloroflexi is a facultative anaerobic bacterium, which has been proved to be effective in eliminating chloride pollution in the environment. In this study, the results showed the following rule: The Nitrospira of the planting system was stronger than that not plant system, but decreased with the increase of substrate depth, Nitrospira on the top layer of system B is remarkably the highest (planting with Pennisetum purpureum Schum.), while the abundance of firmicutes, Bacteroidetes and OP11 in system C were higher than system $\mathrm{A}$ and system $\mathrm{B}$.

At the class level, in total, 53 bacterial taxa were observed. Most predominant bacteria $(>1 \%)$ were ascribed to Betaproteobacteria (averaging $24.1 \%$ ), followed by Deltaproteobacteria (averaging 13.4\%), Alphaproteobacteria (averaging 10.5\%), Gammaproteobacteria (averaging 5.8\%), Clostridia (averaging 4.8\%), Bacteroidia (averaging 4.6\%), Anaerolineae (averaging 4.2\%), Actinobacteria (averaging 1.84\%), Sphingobacteria (averaging 1.80\%), Acidobacteria_Gp7 (averaging 1.63\%), and Nitrospira (averaging 1.4\%). Furthermore, the relative abundance of these groups indicates that the spatial variations of wetland systems are large.

Figure 2(b) showed that proteobacteria mainly was composed of Alpha-, Beta-, Delta- and Gammaproteobacteria. Betaproteobacteria was most richest in these three systems. The distribution of the Deltaproteobacteria showed the following trends: as the substrate depth increased, the Deltaproteobacteria abundance also increased, and this bacterium were the most abundant in system $\mathrm{C}$ (the abundance of $\mathrm{C} 3$ was up to $22.5 \%$ ). Compared to Deltaproteobacteria, Alphaproteobacteria was adverse, and it was most abundant in top layer substrate of these 9 constructed wetlands, while the distribution rule is that the bacterial abundance decreased as substrate depth increased. It showed that the depth of substrate has a strong impact on microbial community structure. 


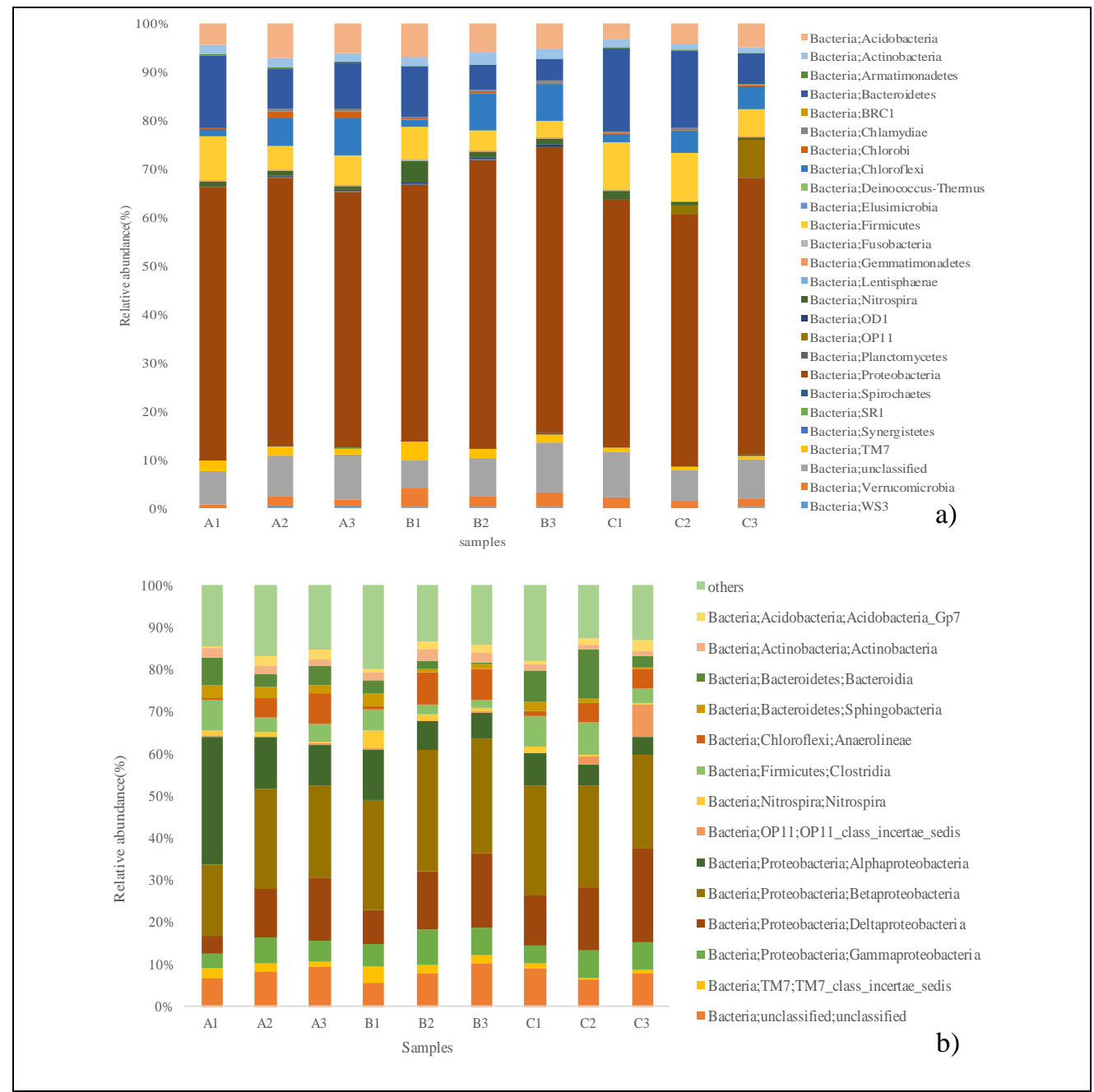

Figure 2. Bacterial community composition in three vertical flow constructed wetland. a) Phylum-level distribution of bacteria; $b$ ) Class-level distribution of bacteria (Others include the bacteria class with the relative abundance less than $1 \%$ in each sample)

\section{Venn analysis}

The common number of OTU (operational taxonomic units) among multiple samples can reflect the similarity and overlap of environmental samples. The statistical results are obtained in the form of Venn diagram. In general, 97\% of OTU at similar levels was selected for analysis, and the number of OTU can also represent the number of bacterial species. From Figure 3, there were some results as followed: The number of bacterial species in system A, system B and system C were $60-90 \mathrm{~cm}>30-60 \mathrm{~cm}>0-30 \mathrm{~cm}$, $60-90 \mathrm{~cm}>0-30 \mathrm{~cm}>30-60 \mathrm{~cm}$ and $30-60 \mathrm{~cm}>60-90 \mathrm{~cm}>0-30 \mathrm{~cm}$, respectively.

\section{Enzymes activities}

Figure 4 illustrated that the changes of urease, phosphatase and cellulose are consistent, and they all reduced with the increase of matrix depth. The rule was shown as followed: $0-30 \mathrm{~cm}>30-60 \mathrm{~cm}>60-90 \mathrm{~cm}$. This is consistent with previous research results. The comparison between this result and Fig. 3 indicates that the number of microorganisms is not necessarily related to the enzyme activity. 


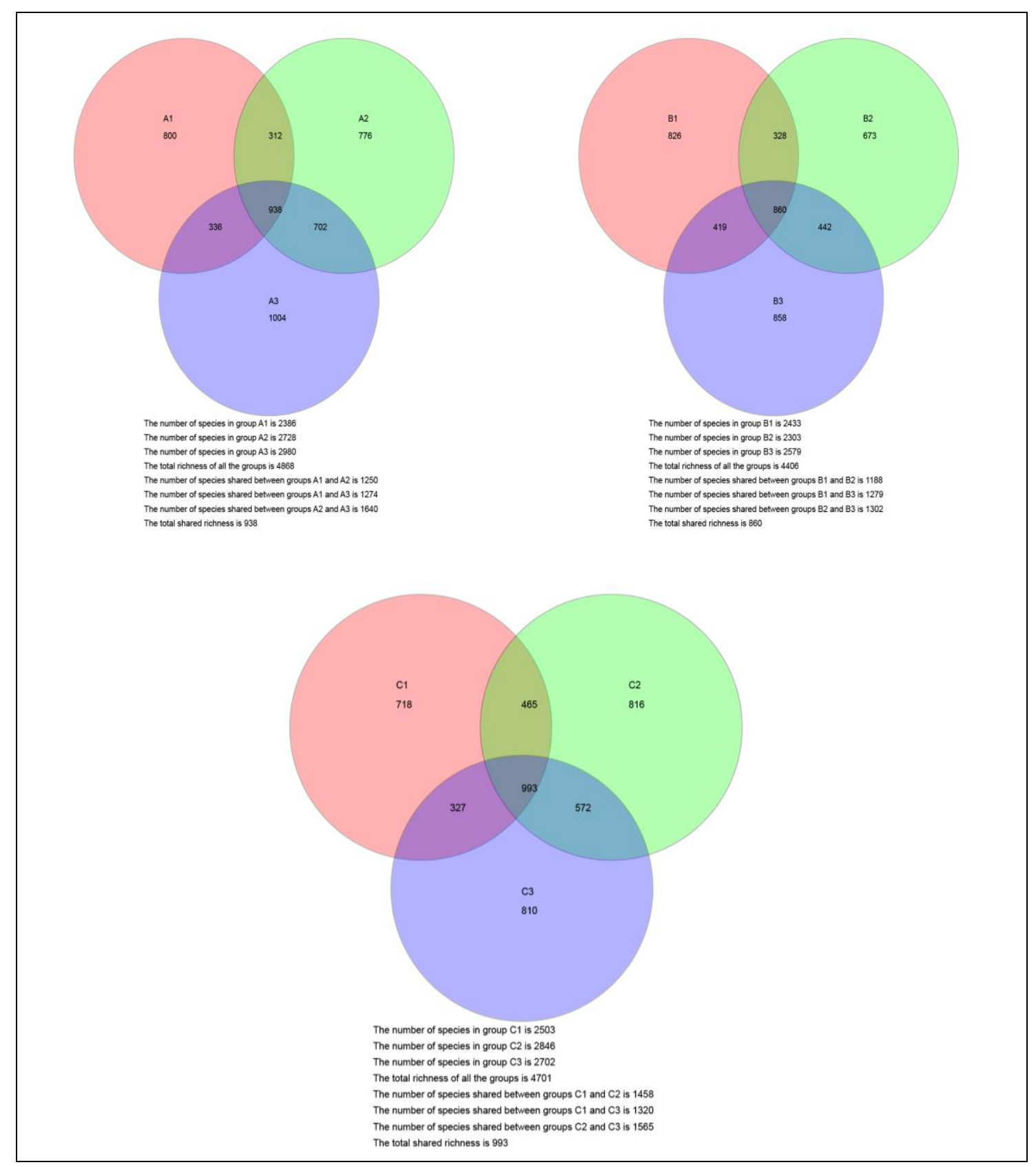

Figure 3. Venn diagram

\section{Water quality change}

Figure 5 illustrated that the changes of TN, TP and COD. The $\mathrm{N}$ removal efficiency in these three $\mathrm{CW}$ systems was about $50-70 \%$. With the operation of the system, the removal rate of TP basically presents a downward trend. After August 15, the P removal efficiency patterns from the three CW systems were in the following order: $\mathrm{B}>\mathrm{A}>\mathrm{C}$, and showed a significant difference in September $12(\mathrm{p}=<0.01)$. The average removal efficiency of COD was higher than $85 \%$ and COD removal performed was satisfied. 


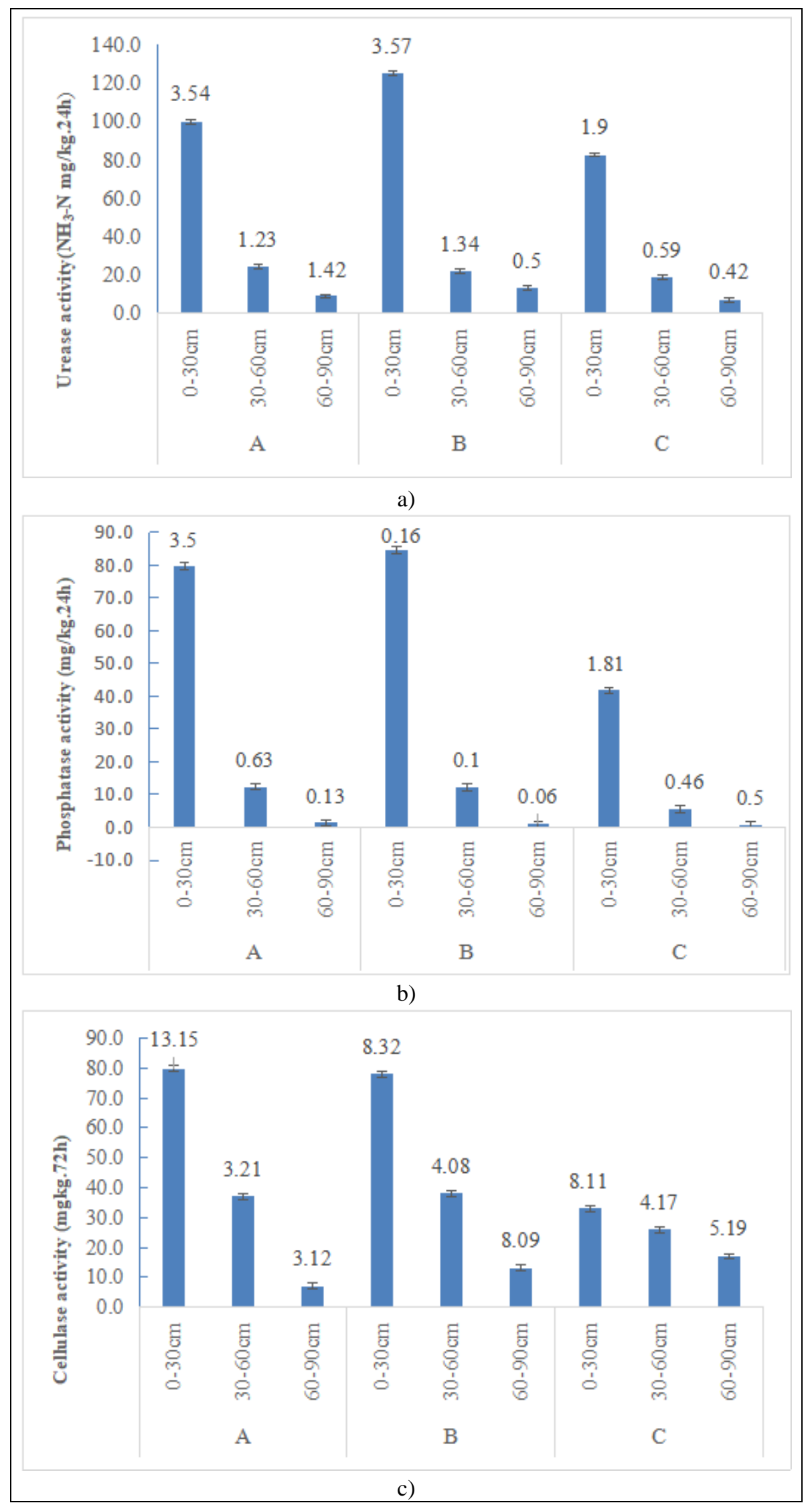

Figure 4. Substrate enzymes dynamic change in three systems

APPLIED ECOLOGY AND ENVIRONMENTAL RESEARCH 18(1):959-971.

http://www.aloki.hu • ISSN 15891623 (Print) • ISSN 17850037 (Online) DOI: http://dx.doi.org/10.15666/aeer/1801_959971

(c) 2020, ALÖKI Kft., Budapest, Hungary 


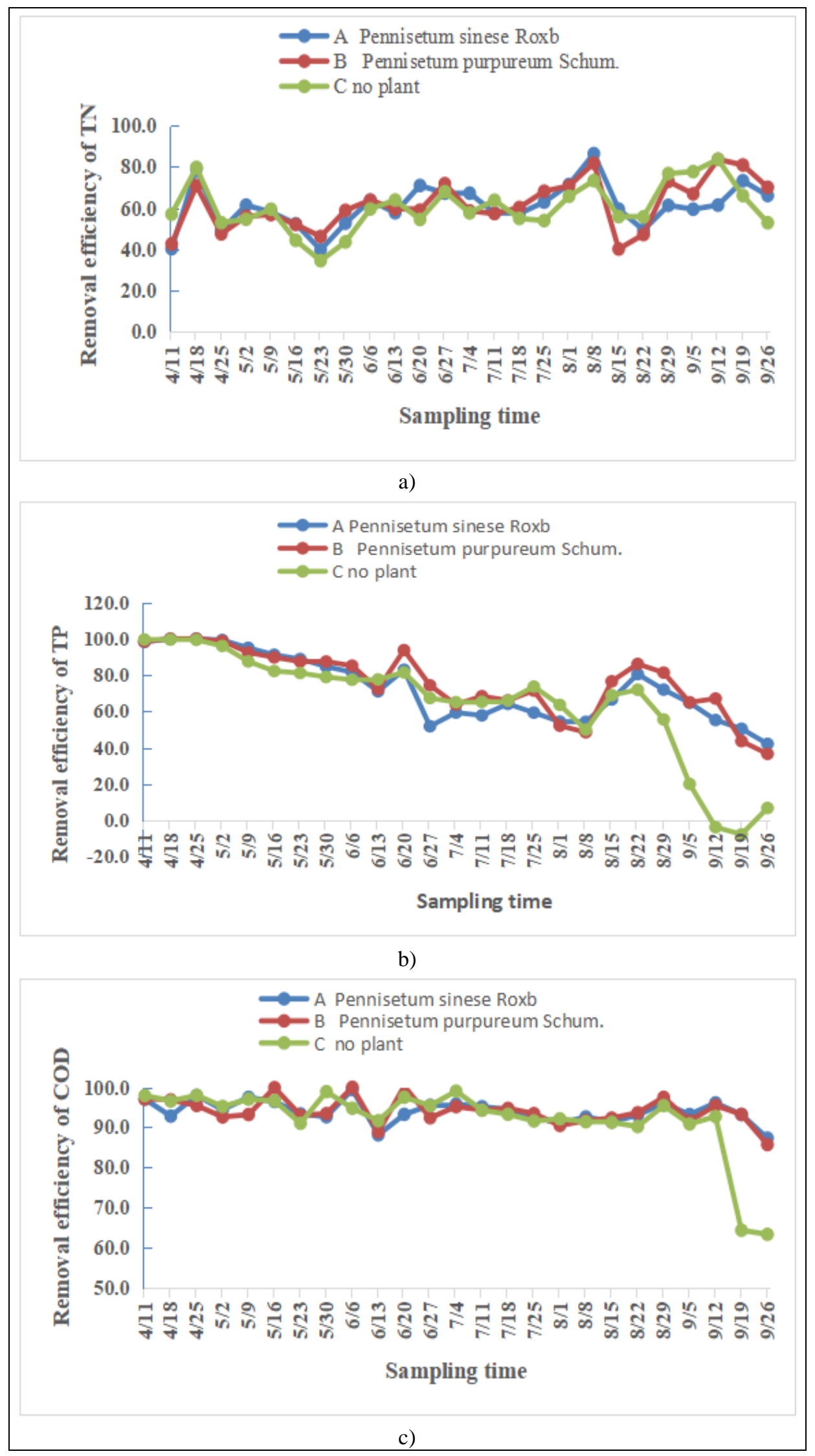

Figure 5. Water monitoring indexes change in three systems 


\section{Discussion}

\section{Microbial community in constructed wetland}

Species diversity is a prerequisite for maintaining the normal function of an ecosystem (Ansola et al., 2014). The richness and diversity of bacterial communities make wetlands play an important ecological role in nutrient cycling, organic degradation, heavy metal morphological transformation and greenhouse gas emissions (Conrad, 1996). Among the 9 soil types of wetland plants in this study area, the abundance and diversity of soil bacterial communities are consistent: Proteobacteria was dominant in 9 studied samples. Proteobacteriagate is a kinds of bacterial community, in the study of many wetland bacteria have the highest relative abundance, such as the Yellow River delta wetland (Yu et al., 2012), China Hong Kong mangrove wetland (Jiang et al., 2013), the United States Olentangy river wetland (Ligi et al., 2014) and artificial wetland (Ansola et al., 2014), etc. The proteobacteria mainly was composed of Alpha-, Beta-, Delta- and Gammaproteobacteria. Betaproteobacteria was most richest in these three systems. Chloroflexi and Nitrospirae in system A and B are remarkably higher than system C, however, the abundance of firmicutes, Bacteroidetes and OP11 in system $\mathrm{C}$ were higher than system $\mathrm{A}$ and system $\mathrm{B}$. These results proved that the presence of vegetation, types of vegetation all can affect the microbial community structure. The regulation of plant collocation could vary the microbial structure distribution, and eventually optimize the decontamination ability of the wetland system. The results can provide theoretical basis for the selection and matching of constructed wetland plants in the future.

\section{Enzyme activity}

The number of microorganisms in system A, system B and system C were 60-90 $\mathrm{cm}>30-60 \mathrm{~cm}>0-30 \mathrm{~cm}, 60-90 \mathrm{~cm}>0-30 \mathrm{~cm}>30-60 \mathrm{~cm}$ and $30-60 \mathrm{~cm}>60-90 \mathrm{~cm}$ $>0-30 \mathrm{~cm}$, respectively. But urease, phosphatase and cellulose were all reduced with the increase of matrix depth. The results showed that the enzyme activity was not necessarily related to the number of microorganisms. Guo (1997) found that the relationship among urease, phosphatase, cellulose activities and microbial biomass were as followed: Enzymes activities increased with the increase of microbial biomass. However, our research was not consistent with it, which may be related to the structure of the VFCW (Aon and Colaneri, 2011) or some function bacterial. Due to the special structure, the oxygen in the upper matrix of the VFCW was relatively sufficient, which was only conducive to the reproduction of aerobic microorganisms. In addition, the enzyme activity of rhizosphere in system A was different from that in system B. Both urease and phosphatase showed that the activity of planting Pennisetum purpureum Schum.'s enzyme was higher than that of planting Pennisetum sinese Roxb's enzyme. Enzyme activity around rhizosphere can not only reflect the bacteria activities in plant root zone, but also reflect the effect of plant spices. Different plants have different influence on secretion of enzymes and microorganisms' growth. Pennisetum sinese Roxb and Pennisetum purpureum Schum. both have large biomass. Therefore, the rhizosphere microorganism quantity and activity are slightly higher. Consequently, Pennisetum sinese Roxb and Pennisetum purpureum Schum. should be the better vegetation choices for construct wetland to remove pollution. 


\section{Water quality changes}

The high removal efficiency of TN and COD in this experiment might be attributed to the higher temperature in summer, resulting in higher microbial activities. Temperature indeed has a great effect on the nutrients removal efficiency of CWs (Fan et al., 2013). It could be related to some functional bacteria, for example the Nitrospira are known for their role in nitrite oxidation (Feng et al., 2013), and the proteobacteria often take advantage of ammonia gas produced by the decomposition of organic matter and may have participated in the biological reaction of various organic matters in nature or artificial systems (Madigan et al., 1997; Liao et al., 2013; Liu et al., 2014). It may indirectly explain the effective removal of TN and COD in these three VFCWs. In addition, a previous study also showed that proteobacterium was dominant in the large-scale CW purification and polluted river system (Wei et al., 2015).

Above all, the variation in microbial structure are most likely to reflect the impact of changes in microbial community of constructed wetland in the balance wetland ecosystem. In future studies, we must focus on the potential mechanisms driving community variation and elucidation of how these variations affect the microbial community function of constructed wetlands.

\section{Conclusion}

(1) There was no direct relationship between microbial species population and enzyme activity. Meanwhile, planting vegetation whether or not, vegetation type and substrate depth may have a great influence on the bacterial community and substrate enzyme in VFCW. This suggests that we could improve pollutant removal by planting different wetland plants and designing different substrate depths to regulate wetland microorganisms.

(2) Proteobacteria predominated in these three systems, which was mainly included Alpha-, Beta-, Delta- and Gammaproteobacteria, and among them Betaproteobacteria was most abundant. Enzyme activity is independent of microbial populations, but could be related to the populations of corresponding functional bacteria, for example Nitrospira may be related to urease. In future studies, we will further research the specific relationship between enzymes and microorganisms in wetland decontamination, and use genetic engineering to study the decontamination mechanism of microorganisms deeply.

Acknowledgements. The authors wish to thank researcher Lin Jingxing of Chinese Academy of Geological Sciences for scientific discussion and comments on earlier versions of the manuscript. This study was also supported by Guizhou normal colleges and technology top-notch talent support program project (qianjiaohe KY [2016]097), Guizhou provincial science and technology plan project (qiankehe LH [2016]7283), Doctoral fund project (asubsjj201607), National Natural Science Foundation of China (41271245) and Construction project of SCAU sewage ecological treatment and water body restoration engineering technology research center (2012gczxA1004) for their financial support.

\section{REFERENCES}

[1] Abou-Elela, S. I., Hellal, M. S. (2012): Municipal wastewater treatment using vertical flow constructed wetlands planted with Canna, Phragmites and Cyprus. - Ecological Enginnering 47: 209-213. 
[2] Ansola, G., Arroyo, P., Sáenz de Miera, L. E. (2014): Characterisation of the soil bacterial community structure and composition of natural and constructed wetlands. Science of The Total Environment 473-474: 63-71.

[3] Aon, M. A., Colaneri, A. C. (2011): II. Temporal and spatial evolution of enzymatic activities and physico-chemical properties in an agricultural soil. - Applied soil Ecology 18(3): 255-270.

[4] Arias, C. A., Brix, H., Marti, E. (2005): Recycling of treated effluents enhances removal of total nitrogen in vertical flow constructed wetlands. - Journal of Environmental Science Health 40(6-7): 1431-1443.

[5] Conrad, R. (1996): Soil microorganisms as controllers of atmospheric trace gases (H2, CO, CH4, OCS, N2O, and NO). - Microbiological Reviews 60(4): 609-640.

[6] Cooper, P. (2005): The performance of vertical flow constructed wetland systems with special reference to the significance of oxygen transfer and hydraulic loading rates. Water Science Technology 51(9): 81-90.

[7] Cui, L. H., Ouyang, Y., Gu, W. J., Yang, W. Z., Xu, Q. L. (2013): Evaluation of nutrient removal efficiency and microbial enzyme activity in a baffled subsurface-flow constructed wetland system. - Bioresource Technology 146: 656-662.

[8] Fan, J. L., Liang, S., Zhang, B., Zhang, J. (2013): Enhanced organics and nitrogen removal in batch-operated vertical flow constructed wetlands by combination of intermittent aeration and step feeding strategy. - Environmental Science \& Pollution Research 20: 2448-2455.

[9] Feng, S., Chen, C., Wang, Q. F., Yang, Z. Y., Zhang, X. J., Xie, S. G. (2013): Microbial community in a full-scale drinking water biosand filter. - J. Environ. Biol. 34: 321-324.

[10] Fu, G. P., Zhang, J. H., Chen, W., Chen, Z. R. (2013): Medium clogging and the dynamics of organic matter accumulation in constructed wetlands. - Ecological Enginnering 60: 393-398.

[11] Guan, S. Y. (1986): Soil enzyme and its research method. - Agricuture Press, Beijing.

[12] Guo, J. X., Jiang, S. C., Lin, H. J., Jin, L. (1997): Enzymic activity of alkaline meadow soil with different grassland vegetations. - Chinese Journal of Applied Ecology 8(4): 412416.

[13] IWA. (2000): Constructed Wetlands for Pollution Control: Processes, Performance, Design and Operation. - Scientific and Technical Report No. 8. International Water Association, London, UK.

[14] Jiang, X. T., Peng, X., Deng, G. H., Sheng, H. F., Wang, Y., Zhou, H. W., Tam, N. F. Y. (2013): Illumia Sequencing of 16S rRNA Tag Revealed Spatial Variations of Bacterial Communities in a Mangrove Wetland. - Microbial Ecology 66(1): 96-104.

[15] Kadlec, R. H., Knight, R. L. (1996): Treatment Wetlands. - Lewis Publishers, Michigan Boca Raton, FL.

[16] Kadlec, R. H., Wallace, S. D. (2008): Treatment Wetlands. - Second ed. CRC Press, Boca Raton, USA.

[17] Kantawanichkul, S., Kladpraserta, S., Brix, H. (2009): Treatment of high-strength wastewater in tropical vertical flow constructed wetlands planted with Typha angustifolia and Cyperus involucratus. - Ecological Enginnering 35: 238-247.

[18] Liao, X. B., Chen, C., Wang, Z., Wan, R., Chang, C. H., Zhang, X. J., Xie, S. G. (2013): Changes of biomass and bacterial communities in biological activated carbon filters for drinking water treatment. - Process Biochem. 48: 312-316.

[19] Ligi, T., Oopkaup, K., Truu, M., Preem, J. K., Nõlvak, H., Mitsch, W. J., Mander, Ü., Truu, J. (2014): Characterization of bacterial communities in soil and sediment of a created riverine wetland complex using high-throughput 16S rRNA amplicon sequencing. - Ecological Engineering 72: 56-66.

[20] Lin, Z., Ye, W., Zu, X. P., Xie, H. S., Li, H. K., Li ,Y. P., Zhang, W. D. (2018): Integrative metabolic and microbial profiling on patients with Spleen-yang-deficiency syndrome. - Scientific reports 8: 1-11. 
[21] Liu, Y., Zhang, J. X., Zhao, L., Zhang, X. L., Xie, S. G. (2014): Spatial distribution of bacterial communities in high-altitude freshwater wetland sediment. - Limnology 15: 249-256.

[22] Madigan, T. M., Martinko, J. M., Parker, J., Brock, T. D. (1997): Brock Biology of Microorganisms. - Upper Saddler River, NJ: Prentice Hall.

[23] Prochaska, C. A., Zouboulis, A. I. (2006): Removal of phosphates by pilot vertical-flow constructed wetlands using a mixture of sand and dolomite as substrate. - Ecological Enginnering 26: 293-303

[24] Prochaska, C. A., Zouboulis, A. I., Eskridge, K. M. (2007): Performance of pilot-scale vertical-flow constructed wetlands, as affected by season, substrate, hydraulic load and frequency of application of simulate urban sewage. - Ecological Enginnering 31: 57-66.

[25] Tang, P., Yu, B. H., Zhou, Y. C., Zhang, Y., Li, J. (2017): Clogging development and hydraulic performance of the horizontal subsurface flow storm water constructed wetlands: a laboratory study. - Environmental Science and Pollution Research 24: 92109219.

[26] Truu, M., Juhanson, J., Truu, J. (2009): Microbial biomass, activity and community composition in constructed wetlands. - Science of the total environment 407: 3958-3971.

[27] Vymazal, J., Kröpfelová, L. (2008): Wastewater Treatment in Constructed Wetlands with Horizontal Sub-Surface Flow. - Series of Environmental Pollution, Vol. 14. Springer, Germany.

[28] Vymazal, J. (2009): Horizontal sub-surface flow and hybrid constructed wetlands systems for wastewater treatment. - Ecological Enginnering 25: 478-490.

[29] Wang, X. D., Zhai, Y. H., Zhao, S., Li, R. Q., Ma, W. L., Li, Y. H. (2009): Effect of free surface flow wetland and subsurface flow wetland on bacterial diversity in Beijing cuihu wetland park. - Environmental Science 30: 280-288. (in Chinese).

[30] Wang, P., Chen, B., Zhang, H. (2017): High throughput sequencing analysis of bacterial communities in soils of a typical Poyang lake wetland. - Acta Ecologica Sinica 37(5): $1652-1658$.

[31] Wei, G., Yin, M., He, T., Xie, S. G. (2015): Influence of substrate type on microbial community structure in vertical-flow constructed wetland treating polluted river water. Environmental Science and Pollution Research 22(20): 16202-16209.

[32] Xu, Q. L., Huang, Z. J., Wang, X. M., Cui, L. H. (2015): Planting Pennisetum sinese Roxb and Pennisetum purpureum Schum. as vertical-flow constructed wetland vegetation for removal of $\mathrm{N}$ and $\mathrm{P}$ from domestic sewage. - Ecological Enginnering 83: 120-124.

[33] Yu, Y., Wang, H., Liu, J., Wang, Q., Shen, T. L., Guo, W. H., Wang, R. Q. (2012): Shifts in microbial community function and structure along the successional gradient of coastal wetlands in Yellow River Estuary. - European Journal of Soil Biology 49: 12-21.

[34] Zhang, C. B., Wang, J., Liu, W. L., Zhu, S. X., Liu, D., Chang, S. X., Chang, J., Ge, Y. (2010): Effects of plant diversity on nutrient retention and enzyme activities in a fullscale constructed wetland. - Bioresource Technology 101: 1689-1692.

[35] Zuritaa, F., De Andab, J., Belmontc, M. A. (2009): Treatment of domestic wastewater and production of commercial flowers in vertical and horizontal subsurface-flow constructed wetlands. - Ecological Enginnering 35: 861-869. 